\title{
Antibacterial Metabolites Obtained from Fermentation of Peanut and Cowpea by Lactobacillus spp
}

\author{
*OYEDOH, PO; OSHOMA, CE; IKENEBUMEH, MJ
}

Department of Microbiology, University of Benin, Benin City, Nigeria.

*Corresponding AuthorEmail; oghoye.oyedoh@uniben.edu

\begin{abstract}
Lactic acid bacteria elective habitat is food matrix, where they release encrypted metabolites from several parent proteins as a result of their proteolytic activity in the matrix. These metabolites when decrypted confer different bioactive activity thus improving public health. This study was aimed at producing peptide containing metabolites with antibacterial efficacy from defatted cowpea and peanut using Lactobacillus spp. Lactobacillus spp. isolated from spoilt yoghurt were identified using culture dependent and independent method. The isolates were screened for proteolytic ability on skimmed milk agar. The selected isolate with highest proteolytic activity was used for metabolites production through fermentation of defatted cowpea and peanut at $37^{\circ} \mathrm{C}$ for $72 \mathrm{~h}$. Parameters analyzed during fermentation were $\mathrm{pH}$, Lactobacillus count, protease activity, peptide concentration and antibacterial activity. The crude peptides produced were assayed for antibacterial activity against bacteria isolated from spoilt meat. From the identified Lactobacillus spp., L. plantarum CAU4347 had the highest proteolytic activity with clear zone of $24.50 \pm 0.707 \mathrm{~mm}$. During fermentation the highest and lowest Lactobacillus counts were from cowpea and peanut media with values 294.2 $\pm 0.21 \times 10^{7}$ and $0.60 \pm 0.4 \times 10^{7} \mathrm{cfu} / \mathrm{ml}$ respectively. Cowpea medium inoculated with L. plantarum CAU4347, had the highest peptide concentration of $79.92 \pm 0.01 \mu \mathrm{g} / \mathrm{ml}$. Consequently, peanut medium showed higher antibacterial activity of $18 \mathrm{~mm}$ against Escherichia coli. This result finding suggests that encrypted peptide metabolites from cowpea and peanut flour can confer antibacterial activity against meat spoilage bacteria thus could be utilized as a potential bio-preservative.
\end{abstract}

DOI: https://dx.doi.org/10.4314/jasem.v24i10.18

Copyright: Copyright $(\subset 2020$ Oyedoh et al. This is an open access article distributed under the Creative Commons Attribution License (CCL), which permits unrestricted use, distribution, and reproduction in any medium, provided the original work is properly cited.

Dates: Received: 15 August 2020; Revised: 22 September 2020; Accepted: 19 October 2020

Keywords: Metabolites, Cowpea, Peanut, Bioactive, Fermentation, Lactobacillus plantarum

Food preservation principle is mainly concerned with preventing microbial spoilage that will result to several negative changes in integrity and loss of nutritional value of food (Rawat, 2015). To suppress the growth and survival of these microorganisms, a process which is dependent on microbial biological activity for metabolites production is used. This is an old method utilized for food and beverage preservation and production thousands of years ago, known as fermentation. Different food varieties have been used by yeast and lactic acid bacteria, in both cases the food acts as substrate for the release of microbial metabolites which contribute to its shelf life extension (Korhonen and Philanto, 2006). Likewise, during bacteria or yeast growth in a protein material medium, enzyme secretion (especially proteases) hydrolyzes the parent protein to release peptides which confer different bioactive activity in their crude and pure forms. The fermentation product can be used directly or could be centrifuged to obtain peptide containing metabolites with lengthy chains and wide array of amino acid compositions (Jakubczyk et al., 2013). Peanut and cowpea are known to have innate beneficial bioactive compounds inherent in their parent protein thus ascribing physiological roles when released (Udenigwe and Aluko, 2012). Asides the nutritional constituents of these legumes, they also contain anti-nutrients which interfere with protein digestibility. These anti-nutrients can be detoxified by dehulling, soaking, boiling, steaming, roasting, sprouting and fermentation treatment (Phulia et al., 2018; Nwafor et al., 2017), leaving behind nutritional compositions for microbial protease hydrolysis. These proteases endogenously or exogenously attack sited small amino or carboxyl group of parent protein (Demirci et al., 2014) to release peptides. These peptides can be applied as functional food additives, animal feed, infant food formulations, fortifier for fruit juice and soft drink as well as specific therapeutic food products (Balakrishnan et al., 2011); or allowed to pass through costly downstream purification process. The high value hydrolyzate containing peptides also exhibited antioxidant, antimicrobial, antihypertensive, anticarcinogenic, immunomodulatory and antithrombotic activities (Hartmann and Meisel, 2007; Chalamaiah et al., 2012; Agyei and Danquah, 2012). Research has revealed crude and pure antimicrobial peptides (AMPs) obtained from soybean, which 
reflects that plant proteins are good source of potential bio-preservative (Biobaku et al., 2017; Dhayakaran et al., 2016). Their activity depends on the protein type used, extent of hydrolysis and the amino acid sequences in the hydrolyzate (Alvarez-Ordonez et al., 2013). The aforementioned hydrolyzate can be formed by the hydrolytic action of lactic acid bacteria (LAB) derived protease on proteins produced by cowpea and peanuts such as globulins, albumins, arachin and coarachin (Osman et al., 2013; Abdel-Shafi et al., 2019) to increase protein content, remove antinutrients content (Adeyemo and Onilude, 2013) and release peptides of bioactive ability (Mohanty et al., 2016). These organisms have displayed impressive attributes as starter culture in peptide assay. They are cheaper, have rapid accelerated metabolic activities, improved safety, reduced hygienic risks and toxigenic risk, shown high viability and survival prowess (Holzapfel, 2002). Species that have been implicated in antimicrobial peptide production are Lactobacillus rhamnosus, L. plantarum, L. acidophilus, $L$. delbreuckii L. paracasei, L. pentosus (Rana and Bajaj, 2015), Bacillus subtilis NB22 and Virgibacillus sp. (Lapsongphon and Yongsawatdigul, 2013). This study was to investigate the antibacterial activity of metabolites produced by Lactobacillus sp. during fermentation of cowpea and peanut.

\section{MATERIALS AND METHOD}

Sample Collection and Preparations: Peanut and cowpea purchased from an open market in Benin City were prepared by soaking $3 \mathrm{~kg}$ of the grains in $6 \mathrm{~L}$ of distilled water for $15 \mathrm{~min}$ and dehulled by crushing inbetween the palms. Then sun-dried for 3 days and ground into powdered form using a hand blender. The powder samples were stored in clean bottles for further laboratory analysis. From each finely ground sample $1000 \mathrm{~g}$ was weighed and mixed with $5 \mathrm{~L}$ analytical nhexane in a Soxhlet apparatus for extraction. After 24 $\mathrm{h}$ of extraction, by constantly recycling $1000 \mathrm{ml}$ of the solvent, the defatted samples were oven dried (Lemfield Medical England, Model DHG) at $40{ }^{\circ} \mathrm{C}$ for $4 \mathrm{~h}$ and allowed to cool (Liu and Chiang, 2008).

Proximate Analysis: The protein, fat, carbohydrate, ash, moisture and fiber contents of dehulled defatted cowpea and peanut samples were determined by the methods of AOAC (1990).

Isolation and characterization of Lactobacillus spp.: Fresh yoghurt was allowed to undergo spoilage after which 10 fold serially dilution was carried out using sterile distilled water as a diluent. An aliquot of the appropriate dilution was spread plated on De Man Rogosa Sharpe agar (MRS) (Oxoid, UK) and incubated at $37^{\circ} \mathrm{C}$ for $48 \mathrm{~h}$. Colonies of interest were identified based on cultural characteristics observed on agar plates and sub-cultured into MRS medium, purified on nutrient agar and transferred to slants. Presumptive selected biochemical screening was carried out on purified colony of selected bacterial isolates sub-cultured on nutrient agar. DNA of the single colony purified on nutrient agar was extracted by following the instruction on the manufacturer's manual on the DNA extraction kits. And pure DNA was amplified using the polymerase chain reaction. The amplified fragments were sequenced (Genetic Analyzer 3130xl sequencer) from Applied Biosystems using sequencing kit (Big Dye Terminator v3.1 Cycle Sequencing kit). Bio-Edit software and MEGA 6 were used for all genetic analysis (Cheesbrough, 2000; Da Trindade et al., 2007).

Screening of Lactobacillus Isolates for Proteolytic Activity: An inoculum of a $24 \mathrm{~h}$ old culture of Lactobacillus isolates on nutrient agar was transferred into MRS broth in test tubes and incubated at $37{ }^{\circ} \mathrm{C}$ for $48 \mathrm{~h}$. Then $10^{8} \mathrm{cfu} / \mathrm{ml}$ suspension was prepared which is equivalent to $0.5 \mathrm{McF}$ arland. And $0.5 \mathrm{ml}$ of the suspension was infused in holes bored (with $6 \mathrm{~mm}$ diameter cork borer) on skim milk agar ( $1 \%$ skim milk, $0.5 \%$ peptone, $0.3 \%$ yeast extract, $15 \%$ agar and 0.5 $\% \mathrm{NaCl}$ ) plate and incubated at $28 \pm 2{ }^{\circ} \mathrm{C}$ for $24 \mathrm{~h}$. After which the zone of clearance was recorded. The highest zone of clearance indicated high proteolytic activity on skim milk. The Lactobacillus isolate with the highest proteolytic activity was selected for metabolite production.

Inoculum Preparation: The screened Lactobacillus isolate with high proteolytic activity was cultured on MRS agar at $37^{\circ} \mathrm{C}$ for $24 \mathrm{~h}$. Cell pellet free from MRS medium was obtained and transferred to a test tube containing $2 \mathrm{ml}$ sterile saline to prepare $10^{8} \mathrm{cfu} / \mathrm{ml}$ inoculum suspensions. The saline containing tube was vortexed to make smooth suspension and the turbidity of each suspension was compared with $0.5 \mathrm{McF}$ arland standards whose absorbance at $625 \mathrm{~nm}$ should be 0.08 to 0.10 , equivalent to $10^{8} \mathrm{cfu} / \mathrm{ml}$.

Fermentation Experiment: From the defatted peanut and cowpea samples $80 \mathrm{~g}$ were weighed into separate $1000 \mathrm{ml}$ conical flasks containing $720 \mathrm{ml}$ distilled water. The $\mathrm{pH}$ of the mixture was stabilized to 6.4 using $0.1 \mathrm{~N} \mathrm{NaOH}$ and/or $\mathrm{HCl}$, then autoclaved at 121 ${ }^{\circ} \mathrm{C}$ for $15 \mathrm{~min}$. The sterile broth was inoculated with 2 $\mathrm{ml}$ suspension of the screened Lactobacillus isolate (equivalent to $1.5 \times 10^{8} \mathrm{cfu} / \mathrm{ml}$ ) and fermented at $37^{\circ} \mathrm{C}$ for $72 \mathrm{~h}$. Samples were analyzed at every $24 \mathrm{~h}$ interval for change in $\mathrm{pH}$, Lactobacilli count, protease activity, peptide concentration and anti-bacterial activity (Singh et al., 2015). 
Viable Lactobacilli Count: Lactobacillus count of the fermented samples was carried out using 10-fold serial dilution and spread plate method. An aliquot of $100 \mu 1$ each was transferred into plate containing De Man Rogosa Sharpe agar (MRS, Oxoid, UK.) and incubated at $37^{\circ} \mathrm{C}$ for $48 \mathrm{~h}$, after which colonies were counted and recorded as cfu/ml (Park et al., 2012).

pH and Protease Activity Determination: The $\mathrm{pH}$ was determined using $\mathrm{pH}$ meter. The protease activity of fermented samples was determined using the azocasein method and absorbance measured at 440nm (Slivinski et al., 2012).

Peptide Extraction and Quantification: Each fermented sample was centrifuged with $10 \mathrm{ml}$ centrifuged tubes at $14000 \mathrm{rpm}$ for $15 \mathrm{mins}$ and the supernatant suspension was adjusted to $\mathrm{pH} 7.0$ using $1 \mathrm{M} \mathrm{NaOH}$ to exclude the antimicrobial effects of organic acid, followed by filtration of the supernatant. Inhibition activity from hydrogen peroxide $\left(\mathrm{H}_{2} \mathrm{O}_{2}\right)$ was eliminated by the addition of $5 \mathrm{mg} / \mathrm{ml}$ catalase and freeze dried at $-40^{\circ} \mathrm{C}$. Peptide quantification was determined on the crude freeze dried peptide samples using the ortho-phthaldehyde (OPA) assay method (Wang et al., 2008) and the absorbance measured spectrophotometrically at $340 \mathrm{~nm}$, after $5 \mathrm{~min}$ at $28 \pm 2$ ${ }^{\circ} \mathrm{C}$. The standard serine curve was determined using serine concentration range of $25-250 \mu \mathrm{g} / \mathrm{ml}$ and the peptide concentration was estimated by extrapolation from the standard curve.

Antibacterial Activity: The test organisms used for antibacterial activity of crude metabolites were Bacillus cereus, Salmonella enteritidis, Enterobacter cloacae, Klebsiella variicola, Pseudomonas aeruginosa, Staphylococcus aureus and Escherichia coli. The test organisms were collected from the Department of Microbiology Laboratory, University of Benin, Benin City and confirmed using culture based method (Cheesbrough, 2000). To determine the antibacterial activity (using agar well diffusion method) of peptides, $50 \mathrm{mg} / \mathrm{ml}$ crude freeze dried peptide sample was prepared and $1000 \mu \mathrm{l}$ of it was infused into wells carried on Mueller Hinton agar containing plates with a cork borer of $6 \mathrm{~mm}$ in diameter.

These plates have been prepared by inoculating with $100 \mu \mathrm{l}$ broth containing each test organism (grown overnight at $37^{\circ} \mathrm{C}$ and standardized to $10^{8} \mathrm{cfu} / \mathrm{ml}$ using McFarland methods) using the spread plate method. Then the zone of inhibition was measured after $24 \mathrm{~h}$ of incubation in $\mathrm{mm}$ and ciprofloxacin was used as positive control.

Statistical Analysis: During this experiment all data obtained were subjected to variance analysis at $\mathrm{P}<0.05$ using SPSS 15.0 software package. Duncan's New Multiple Range Test was used to separate means (Ogbeibu, 2005).

\section{RESULTS AND DISCUSSION}

The nutritional composition of dehulled defatted peanut and cowpea meal is presented in Table 1. From the composition, cowpea had the highest carbohydrate content of $52.92 \pm 1.36 \%$ followed by protein content of $28.59 \pm 0.77 \%$ and the least $2.00 \pm 0.00 \%$ was crude fat. For peanut, the highest composition was protein content followed by carbohydrate content and the least was crude fat, with values of $49.29 \pm 0.77 \%$, $29.37 \pm 1.95 \%$ and $1.33 \pm 0.33 \%$ respectively. The carbohydrate concentration of both samples, serve as carbon and energy sources required for cell growth (Godbey, 2014). Proteinous foods are sources of encrypted biopeptides and amino groups released through enzyme hydrolysis or fermentation which confer different bioactive activity (Aluko, 2015). Higher protein and lower carbohydrate content observed in defatted peanut sample correlate with studies carried out by Khalid and Elhardallou, (2013) who observed that the protein content of defatted cowpea flour is $26.73 \%$, which is lower than that of defatted peanut $(55.88 \%)(\mathrm{Wu}$ et al., 2009) Biochemical and molecular characterization of the Lactobacillus spp. isolated from spoilt yoghurt is shown in Table 2.

Table 1: Nutritional composition of defatted legume seeds

\begin{tabular}{lll}
\hline Chemical analysis & Cowpea & Peanut \\
\hline Moisture content (\%) & $7.33 \pm 1.30$ & $8.67 \pm 1.67$ \\
Ash content (\%) & $5.67 \pm 0.33$ & $10.00 \pm 1.16$ \\
Crude fat $(\%)$ & $2.00 \pm 0.00$ & $1.33 \pm 0.33$ \\
Crude fibre (\%) & $3.50 \pm 0.29$ & $1.33 \pm 0.17$ \\
Protein content (\%) & $28.59 \pm 0.77$ & $49.29 \pm 0.77$ \\
Carbohydrate content (\%) & $52.92 \pm 1.36$ & $29.37 \pm 1.95$ \\
\hline \multicolumn{2}{l}{ Legend: Values are mean \pm standard deviation of triplicate. }
\end{tabular}

The identified isolates coded L5, L7, L9, L11 were 99 \% similar to Lactobacillus plantarum CAU4347, Lactobacillus pentosus NRIC 1557, Lactobacillus plantarum SNK12 and Lactobacillus plantarum L142 respectively. Isolated Lactobacillus spp. displayed diverse level of zone of clearance $(\mathrm{mm})$ on skimmed milk agar which is indicative of proteolytic ability as shown in Table 3. The highest zone of clearance of $24.50 \pm 0.71 \mathrm{~mm}$ was produced by $L$. plantarum CAU4347 while the least of $19.00 \pm 1.41 \mathrm{~mm}$ was produced by L. plantarum SNK12. 
Table 2: Biochemical and molecular characterization using 16S rRNA gene of Lactobacillus from yoghurt

\begin{tabular}{lllllll}
\hline $\begin{array}{l}\text { Isolate } \\
\text { code }\end{array}$ & $\begin{array}{l}\text { Gram } \\
\text { reaction }\end{array}$ & $\begin{array}{l}\text { Catalase } \\
\text { test }\end{array}$ & $\begin{array}{l}\text { Spore } \\
\text { formation }\end{array}$ & $\begin{array}{l}\text { Identity } \\
(\%)\end{array}$ & $\begin{array}{l}\text { Accession } \\
\text { number }\end{array}$ & Confirmed strains \\
\hline L5 & + & - & - & 99 & MF424125.1 & Lactobacillus plantarum CAU4347 \\
L7 & + & - & - & 99 & AB362714.1 & Lactobacillus pentosus NRIC 1557 \\
L9 & + & - & - & 99 & KX426268.1 & Lactobacillus plantarum SNK12 \\
L11 & + & - & - & 99 & JQB01723.1 & Lactobacillus plantarum L142 \\
\hline
\end{tabular}

The proteolytic activity of Lactobacillus spp. have revealed the ability of all isolates to secrete extracellular proteolytic enzymes by being able to hydrolyze casein molecules into colourless peptide fragments as reflected by the clear zone around each culture. Pailin et al. (2001) conducted a similar study and reported all LAB isolates to produce high zone of clearance on skim milk. In this study, Lactobacillus plantarum CAU4347 had the highest zone of clearance. This isolate can be an efficient and high yielding proteolytic LAB that could have the potential of liberating bioactive peptides from parent proteins (Virtanum et al., 2007). Various authors have reported that L. plantarum has a high proteolytic activity (Toe et al., 2019).

Table 3: Zone of clearance ( $\mathrm{mm}$ ) on skimmed milk agar using the isolated Lactobacillus spp.

\begin{tabular}{ll}
\hline Lactobacillus spp. & Zone of clearance \\
\hline Lactobacillus plantarum CAU4347 & $24.50 \pm 0.71$ \\
Lactobacillus pentosus NRIC 1557 & $21.50 \pm 1.41$ \\
Lactobacillus plantarum SNK12 & $19.00 \pm 1.41$ \\
Lactobacillus plantarum L142 & $20.00 \pm 0.71$ \\
\hline
\end{tabular}

Values are mean \pm standard deviation of duplicate.

L. plantarum CAU4347 was selected for production of antibacterial metabolites through the fermentation of defatted cowpea and peanut proteins. The change in $\mathrm{pH}$ during Lactobacillus plantarum CAU4347 fermentation of peanut and cowpea is shown in Table 4. There was a decrease in $\mathrm{pH}$ as fermentation time progressed. The lowest $\mathrm{pH}$ at $72 \mathrm{~h}$ of fermentation was $5.19 \pm 0.18$ and $5.36 \pm 0.33$ in the peanut and cowpea media respectively. Table 5 showed the viable Lactobacillus count during fermentation of peanut and cowpea. There was a progressive increase of Lactobacillus cell counts during the fermentation period. At $72 \mathrm{~h}$ of fermentation, the highest Lactobacillus count was $294.2 \pm 0.21 \times 10^{7} \mathrm{cfu} / \mathrm{ml}$ from cowpea medium, while the least was $180.81 \pm 0.13$ $\times 10^{7} \mathrm{cfu} / \mathrm{ml}$ from peanut medium. The significant decrease in $\mathrm{pH}$, is attributed to lactic acid produced, thus causing an increase in the acidity of the medium (Thu et al., 2011). Singh and co-workers (2015) observed increase in acidic level as the fermentation time increases during the production of antimicrobial peptides from soy milk protein by Lactobacillus spp. On the contrary, the increase in growth of $L$. plantarum CAU4347 could be as a result of difference in medium composition, which has a number of factors that affect growth and functionality of LAB (Abbasiliasi et al., 2017). The highest L. plantarum CAU4347 growth observed in cowpea medium after $72 \mathrm{~h}$ of fermentation could be as a result of the presence of sufficient carbon and energy source in the medium, utilizable for growth over a longer period of time than its lower carbohydrate containing medium counterpart. These observations aligned with Rana and Bajaj's (2015) research findings, which shows an increase in L. acidophilus and L. delbrueckii from 14 $\mathrm{h}$ to $48 \mathrm{~h}$.

Table 4: Changes in $\mathrm{pH}$ during fermentation of defatted legume seeds

\begin{tabular}{|c|c|c|c|c|c|}
\hline \multirow{2}{*}{$\begin{array}{l}\text { Fermentation } \\
\text { Time(h) }\end{array}$} & \multicolumn{2}{|l|}{ Peanut } & \multicolumn{2}{|l|}{ Cowpea } & \multirow[t]{2}{*}{$P$-value } \\
\hline & Control & L. plantarum & Control & L. plantarum & \\
\hline 0 & $6.43 \pm 0.03^{\mathrm{a}}$ & $6.40 \pm 0.06^{\mathrm{a}}$ & $6.40 \pm 0.06^{\mathrm{a}}$ & $6.40 \pm 0.06^{\mathrm{a}}$ & 0.958 \\
\hline 24 & $6.39 \pm 0.03^{\mathrm{a}}$ & $5.65 \pm 0.13^{b}$ & $6.33 \pm 0.03^{\mathrm{a}}$ & $5.91 \pm 0.11^{b}$ & 0.002 \\
\hline 48 & $6.37 \pm 0.08^{\mathrm{a}}$ & $5.46 \pm 0.3^{\mathrm{b}}$ & $6.28 \pm 0.07^{\mathrm{a}}$ & $5.68 \pm 0.04^{b}$ & 0.013 \\
\hline 72 & $6.35 \pm 0.06^{\mathrm{a}}$ & $5.19 \pm 0.18^{b}$ & $6.30 \pm 0.02^{\mathrm{a}}$ & $5.36 \pm 0.33^{\mathrm{b}}$ & 0.006 \\
\hline
\end{tabular}

Legend: Values are mean \pm standard error of triplicate. Same superscript alphabets across the row mean statistically not significant while those with different superscript means statistically significant $(p<0.05)$

Table 5: Lactobacillus counts $\left(\times 10^{7} \mathrm{cfu} / \mathrm{ml}\right)$ during fermentation of defatted legume seeds

\begin{tabular}{|c|c|c|c|c|c|}
\hline \multirow{2}{*}{$\begin{array}{l}\text { Fermentation } \\
\text { Time(h) }\end{array}$} & \multicolumn{2}{|l|}{ Peanut } & \multicolumn{2}{|l|}{ Cowpea } & \multirow{2}{*}{$P$-value } \\
\hline & Control & L. plantarum & Control & L. plantarum & \\
\hline 0 & $0.60 \pm 0.4^{\mathrm{a}}$ & $1.50 \pm 0.5^{\mathrm{b}}$ & $0.60 \pm 0.4^{\mathrm{a}}$ & $1.70 \pm 0.3^{b}$ & 0.001 \\
\hline 24 & $5.00 \pm 0.4^{\mathrm{a}}$ & $136.62 \pm 0.11^{\mathrm{b}}$ & $3.45 \pm 0.26^{\mathrm{a}}$ & $282.7 \pm 0.23^{\mathrm{c}}$ & 0.000 \\
\hline 48 & $9.80 \pm 0.72^{\mathrm{a}}$ & $147.6 \pm 0.17^{\mathrm{b}}$ & $4.50 \pm 0.35^{\mathrm{a}}$ & $206.3 \pm 0.19^{\mathrm{c}}$ & 0.000 \\
\hline 72 & $11.00 \pm 0.17^{\mathrm{a}}$ & $180.81 \pm 0.13^{b}$ & $8.60 \pm 0.11^{\mathrm{a}}$ & $294.2 \pm 0.21^{\mathrm{c}}$ & 0.000 \\
\hline
\end{tabular}

Legend: Values are mean \pm standard error of triplicate. Same superscript alphabets across the row mean statistically not significant while those with different superscript means statistically significant $(p<0.05)$. 
Protease activity during fermentation of defatted cowpea and peanut by L. plantarum CAU 4347 is presented in Figure 2. The highest protease activity was observed at $24 \mathrm{~h}$ of fermentation with values of $80.56 \pm 1.10$ and $125.88 \pm 1.7$ for peanut and cowpea medium respectively. The least protease activity was observed at $72 \mathrm{~h}$ of fermentation with values of $4.16 \pm$ $0.09 \mathrm{U} / \mathrm{ml}$ and $13.09 \pm 0.17 \mathrm{U} / \mathrm{ml}$ for peanut and cowpea media respectively. Shown in Figure 3 is the concentration of peptides produced when cowpea and peanut media were fermented by $L$. plantarum CAU 4347 for $72 \mathrm{~h}$. At $48 \mathrm{~h}$ of fermentation the highest peptide concentration of $63.64 \mu \mathrm{g} / \mathrm{ml}$ and $79.92 \mu \mathrm{g} / \mathrm{ml}$ were produced in peanut and cowpea media respectively. The least concentration of peptides of $25.83 \mu \mathrm{g} / \mathrm{ml}$ and $37.00 \mu \mathrm{g} / \mathrm{ml}$ in peanut and cowpea media were produced at $72 \mathrm{~h}$ of fermentation. $L$. plantarum displayed a significant increase in protease activity (quantitative) at $24 \mathrm{~h}$ of fermentation followed by a subsequent decrease with both parent proteins. The same medium which encouraged higher count had the highest protease activity of $125.88 \pm 0.72 \mathrm{U} / \mathrm{ml}$ at $24 \mathrm{~h}$. Similar finding was reported by Vij et al. (2014), who observed higher proteolytic activity of 839 tyrosine units / $\mathrm{ml}$ with Lactobacillus spp. Proteolytic hydrolysis of L. plantarum could release encrypted amino groups of long or short sequence (peptide) which could be assessed through OPA method (Hati et al., 2015). The result from OPA assay using serine as standard amino group revealed that L. plantarum fermented cowpea displaying higher peptide concentration than peanut which could be as a result of its high growth rate in the medium. In addition, the highest protease produced at $24 \mathrm{~h}$ in cowpea medium could break down protein to peptides, hence resulting to peptide accumulation at $48 \mathrm{~h}$ of fermentation. The peptide concentration at $48 \mathrm{~h}$ is higher than the original peptide constituent of flour at $0 \mathrm{~h}$ prior to fermentation. This increase after fermentation is as a result of the proteolytic action of proteases produced by Lactobacillus plantarum. The protease breakdown protein into their lower molecular weight peptides and amino acid sequences. These encrypted amino sequences confer different bioactive activities (Singh et al., 2015). Aqueous crude peptide extracts obtained from cowpea and peanut media displayed different level of antibacterial activity against the test isolates used (Table 6). Crude extract from peanut had the highest antibacterial activity exhibited by an inhibition zone of $18.00 \pm 0.20$ against E. coli isolates. Cowpea derived extract displayed the least inhibition zone of $11.00 \pm 0.00$ against E. coli. This possibly suggests defatted peanut medium to be a preferable substrate for antimicrobial peptide production than cowpea. In a study conducted by Rana and Bajaj (2015) on the antimicrobial peptides generation from milk proteins by Lactobacillus spp. under different conditions, they discovered a negative correlation among proteolysis activity and antimicrobial activity. As a result of loss in active peptide formed and appearance of new ones (Donkor et al., 2007). Furthermore, uninoculated peanut broth which was used as the control reflected zone of inhibition of $8 \mathrm{~mm}$ and $6 \mathrm{~mm}$ against E.coli and Salmonella enteritidis respectively. This is possible because peanut seed (and other plant material) has been shown to contain secondary metabolites like phytochemical which confer antibacterial activity and other bioactive activities (Mythily and Revathi, 2017). Therefore, cowpea and peanut proteins are utilizable for L. plantarum growth, proteolytic activity and peptide release but the antibacterial activity of crude peptide extracts could be attributed to the combined effects of diverse peptide fractions with different amino acid composition (not solely serine amino group as reflected in this study).

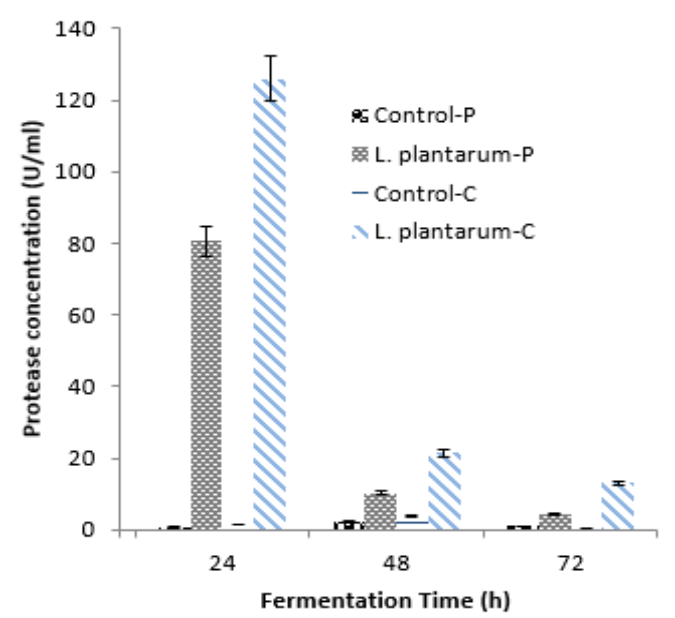

Fig 2: Protease activity of fermented dehulled defatted peanut and cowpea for a fermentation period of 72h. Key: P-peanut; Ccowpea.

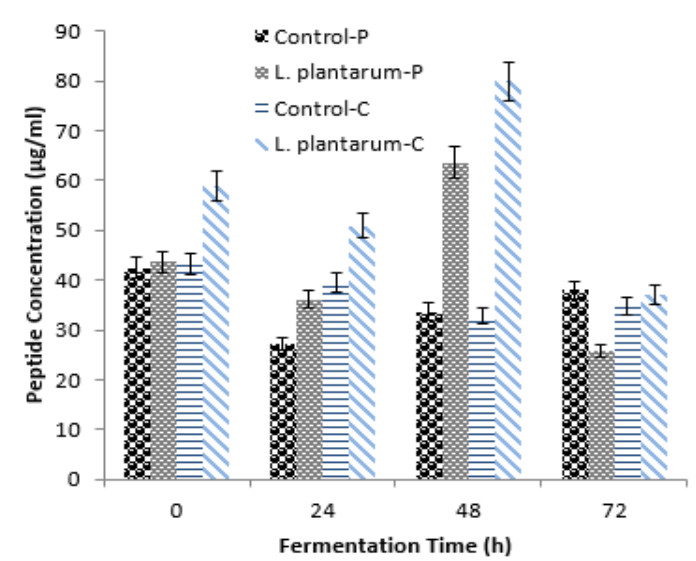

Fig 3: Peptide content in crude freeze dried-fermented peanut and cowpea. Values are mean \pm standard error of triplicate. Key: Ppeanut; C-cowpea. 
Table 6: Antibacterial activity of crude products from freeze dried fermented dehulled defatted legume seeds against bacterial isolates

\begin{tabular}{lllllll}
\hline \multirow{2}{*}{ Test Isolates } & \multicolumn{2}{c}{ Peanut } & & \multicolumn{2}{c}{ Cowpea } & \multirow{2}{*}{ P-value } \\
\cline { 2 - 3 } \cline { 5 - 6 } \cline { 5 - 6 } Control & \multicolumn{1}{c}{ L. plantarum } & & Control & L. plantarum & \\
\hline B. cereus & $0.00 \pm 0.00^{\mathrm{a}}$ & $8.00 \pm 0.00^{\mathrm{b}}$ & & $0.00 \pm 0.00^{\mathrm{a}}$ & $0.00 \pm 0.00^{\mathrm{a}}$ & $<0.05$ \\
S. enteritidis & $6.00 \pm 0.30^{\mathrm{b}}$ & $17.00 \pm 0.00^{\mathrm{c}}$ & & $0.00 \pm 0.00^{\mathrm{a}}$ & $0.00 \pm 0.00^{\mathrm{a}}$ & 0.00 \\
E. cloacae & $0.00 \pm 0.00^{\mathrm{a}}$ & $13.00 \pm 0.20^{\mathrm{b}}$ & & $0.00 \pm 0.00^{\mathrm{a}}$ & $12.00 \pm 0.00^{\mathrm{c}}$ & 0.00 \\
K. variicola & $0.00 \pm 0.00$ & $16.00 \pm 0.00$ & & $0.00 \pm 0.00$ & $16.00 \pm 0.00$ & $<0.05$ \\
$P$. aeruginosa & $0.00 \pm 0.00^{\mathrm{a}}$ & $12.00 \pm 0.20^{\mathrm{b}}$ & & $2.00 \pm 0.00^{\mathrm{c}}$ & $14.00 \pm 0.00^{\mathrm{d}}$ & 0.00 \\
$S$. aureus & $0.00 \pm 0.00$ & $12.00 \pm 0.00$ & & $0.00 \pm 0.00$ & $0.00 \pm 0.00$ & $<0.05$ \\
E. coli & $8.00 \pm 0.00^{\mathrm{a}}$ & $18.00 \pm 0.20^{\mathrm{b}}$ & & $4.00 \pm 0.00^{\mathrm{c}}$ & $11.00 \pm 0.00^{\mathrm{d}}$ & 0.00
\end{tabular}

Conclusion: This study has shown that L. plantarum CAU4347 could proteolyze peanut substrate best compared to cowpea for encrypted antibacterial peptides release from the parent protein. These antibacterial peptides are antagonistic against some meat spoilage isolates, hence their possible usage as meat bio-preservative.

\section{REFERENCES}

Abbasiliasi, S; Shun-Tan, J; Azmi, T; Ibrahim, T; Bashokouh, F; Ramakrishnan, N; Mustafaab, S; Ariff, A (2017). Fermentation Factors Influencing the Production of Bacteriocins by Lactic Acid Bacteria: A Review. The Royal Soc. Chem. Adv. 7: 29395-29420.

Abdel-Shafi, S; Mohammadi, A; Osman, A; Erian, G; Abdel-Hameid, S; Sitohy, M (2019). Characterization and antibacterial activity of $7 \mathrm{~S}$ and $11 \mathrm{~S}$ globulins isolated from cowpea seed protein. Molecules 24(6): 1082.

Adeyemo, SM; Onilude, AA (2013). Enzymatic reduction of anti-nutritional factors in fermenting soybeans by Lactobacillus plantarum isolates from fermenting cereals. Nig. Food J. 31(2): 8490 .

Agyei, D; Danquah, KM (2012). Rethinking foodderived bioactive peptides for antimicrobial and immunomodulatory activities. Trends in Food Sci. Tech. 23(2): 62-69

Aluko, ER (2015). Antihypertensive peptide in food proteins. Ann. Rev. Food Sc. Tech. 6: 235-262.

Alvarez-Ordonez, A; Begley, M; Clifford, T; Deasy, T; Consldine, K; Hill, C (2013). Structure-activity relationship of synthetic variants of the milkderived antimicrobial peptide as2-casein $\mathrm{f}$ (183207). App. Environ. Micro. 79(17): 5179-5185.

Association of Official Analytical Chemistry (AOAC) (1990). Official Methods of Analysis (15 th Ed).Washington, D C, 368pp.
Balakrishnan, B; Prasad, B; Rai, KA; Suresh, PV; Subbanna, NM; Narayan, B (2011). Invitro antioxidant and antibacterial properties of hydrolyzed proteins of delimed tannery fleshings: comparison of acid hydrolysis and fermentation methods. Biodeg. 22(2): 287-285.

Biobaku, KT; Thomas, A; Aremu, NT; Asogwa, SA; Akorede, GJ; Basiru, A (2017). Nutritive effects of fermented Parkia biglobosa seeds on recovery of malnourished rats. Ceylon J. Sci. 46(3): 47-53.

Chalamaiah, M; Kumar, DB; Hemalatha, R; Tummala, J (2012). Fish protein hydrolyzates: proximate, composition, amino acid composition, antioxidant activities and applications: A review. Food Chem. 135(4): 3020-3038.

Cheesbrough, M (2000). Distinct Laboratory Practice in Tropical Countries, Part 2. (2nd Ed). Cambridge University Press, Cambridge 442 pp.

Da Trindade, CL; Marques, E; Lopez, BD; Ferraira, VSAM (2007). Development of a molecular method of detection and identification of Xanthomonas campestris pv. Viticola. Summa Phytopathologica 33(1):16-23.

Demirci, S; Ustaoglu, Z; Yilmazer, AG; Sahin, F; Bac, $\mathrm{N}$ (2014). Antimicrobial properties of zeolites-X and zeolite-A ion exchanged with silver, copper and zinc against abroad range of microorganisms. Appl. Biochem. Biotech. 172: 1652-1662.

Dhayakaran, R; Neethirajan, S; Weng, X (2016). Investigation of the antibacterial activity of soy peptides by developing a high throughput drug screening assay. Biochem. Biophy. Reports 6: 149-157.

Donkor, O; Henriksson, A; Vasiljevic, T; Shah, NP (2007). Proteolytic activity of diary lactic acid bacteria and probiotics as determinant of growth and invitro angiotensin-converting enzyme inhibitory activity in fermented milk. Le Lait 87 : 21-28. 
Godbey, TW (2014). Fermentation, beer and biofuel. In: An Introduction to Biotechnology: the Science, Technology and Medical Application Woodhead Publishing, Cambridge, United Kingdom, p331-351.

Hartmann, R. and Meisel, H (2007). Food-derived peptides with biological activity: from research to food applications. Food Biotech 18:163-169.

Hati, S; Sreeja, V; Solanki, J; Prajapat, JB (2015). Significance of proteolytic microorganisms on ACE-inhibitory activity and release of bioactive peptides during fermentation of milk. J. Dairy Sci. 68(6): 584-597.

Holzapfel, WH (2002). Appropriate starter-culture technologies for small-scale fermentation in developing countries. Int'l. J. Food Microb. 75: 197-212.

Jakubczyk, A; Karas, M; Baraniak, B; Pietrzak, M (2013). The impact of fermentation and in vitro digestion on formation angiotensin converting enzyme (ACE) inhibitory peptides from pea proteins. Food Chem. 141:3774-80.

Khalid, II; EIharadallou, SB (2013). Functional properties of Cowpea (Vigna Ungiculata L.Walp.), Lupin (Lupinus termis) flour and protein isolates. J. Nutr. Food Sci. 3(6): 2-6.

Korhonen, H; Pihlanto, A (2006). Bioactive peptides: production and functionality. Int'l. Dairy J. 16: 945-960.

Lapsongphon, N; Yongsawatdigul, J (2013). Production and purification of antioxidant peptides from a mungbean meal hydrolyzate by Virgibacillus sp. SK37 proteinase. Food Chem. 141: 992-999.

Liu, B; Chang, P (2008). Production of hydrolysate with antioxidative activity and functional properties by enzymatic hydrolysis of defatted sesame (Sesamum indicum L.). Int'l. J. App. Sci. Eng. 6(2): 73-83.

Mohanty, DP; Mohapatra, S; Misra, S; Sahu, PS (2016). Milk derived bioactive peptides and their impact on human health-A review. Saudi J. Bio. Sci. 23: 577-583.

Mythily, K; Revathi, K (2017). Preliminary phytochemical analysis and antimicrobial evaluation of Arachis hypogea L. Int'l. J. Curr. Res. Med. Sci. 3(3): 76-82.

Nwafor, IF; Egonu, NS; Nweze, ON; Ohabuenyi, NS (2017). Effects of processing methods on the nutritional values and anti-nutritive factors of Adenanthera pavonina L. (Fabaceae) seeds. Afri. J. Biotech. 16(3): 106-112.

Ogbeibu, AE (2005). Biostatistics: A Practical Approach to Research and Data Handling. Mindex Publishing Company Limited, Benin City Edo State, Nigeria 264pp.

Osman, AO; Mahgoub, SA; Sitohy, MZ (2013). Preservative action of 11S (glycinin) and 7S ( $\beta$ conglycinin) soy globulin on bovine raw milk stored either at 4 or 25 C. J. Dairy Res. 80:174183.

Pailin, T; Kang, DH; Schmidt, K; Fung, DYC (2001). Detection of extracellular bound proteinase in EPS-producing lactic acid bacteria cultures on skim milk agar. J Appl. Microb. 33(1):45-49.

Park, M; General, T; Lee S (2012). Physicochemical properties of roasted soybean flour bioconverted by solid-state fermentation using Bacillus subtilis and Lactobacillus plantarum. Prev. Nutri. Food Sci. 17: 36-45.

Phulia, V; Sardar, P; Sahu, PN; Sanap, NB (2018). Effect of detoxification methods on antinutritional factors and proximate composition of defatted Jatropha curcas kernel meal. Animal Nutrition and Feed Technology 18(1): 67-77.

Rana, S; Bajaj, R (2015). Optimization of conditions for generation of antimicrobial peptides from milk proteins by Lactobacillus sp. Afri. J. Microb. Res. 9(24): 1573-1585.

Rawat, S (2015). Food spoilage: microorganisms and their prevention. Asian J. of Pt. Sci. Res. 5(4): $47-$ 56.

Singh, BP; Vij, S; Hati, S; Singh, D; Kumari, P; Minj, J (2015). Antimicrobial activity of bioactive peptides derived from fermentation of soymilk by Lactobacillus plantarum $\mathrm{C}_{2}$ against foodborne pathogens. Int'l. J. Ferm. Foods 4: 91-99.

Slivinski, CT; Mallmann, E; De Araujo, MJ; Mitchell, AD; Krieger, N (2012). Production of surfactin by Bacillus pumilus UFPEDA 448 in solid state fermentation using a medium based on okara with 
sugar cane bagasse as a bulking agent. Process Biochem. 47: 1848-1855.

Thu, TV; Foo, HL; Loh, TC; Bejo, MH (2011). Inhibitory activity and organic acid concentration of metabolite combinations produced by various strains of L. plantarum. Afr. J. Biotech. 10: 13591356.

Toe, JC; Foo, LH; Loh, CT; Mohammad, R; Rahun, AR; Idrus, Z (2019). Extracellular proteolytic activity and amino acid production by lactic acid bacteria isolated from Malaysian foods. Int'l. J. Mol. Sci. 20: 1777-1799.

Udenigwe, CC; Aluko, ER (2012). Food proteinderived bioactive peptides: production, processing and potential health benefits. J. Food Sci. 1: 327-341.

Vij, S; Chandra, P; Bachanti, RP (2014). Antimicrobial activity of casein fermentate of probiotic Lactobacillus spp. Int'l J. Genetic Engineer. Biotech. 5(2): 201-208.
Virtanum, T; Pihlanto, A; Akkanen, S; Korhonen, H (2007). Development of antioxidant activity in milk whey during fermentation with lactic acid bacteria. J. Appl. Micro. 102(1): 106-115.

Wang, YK; He, HL; Chen, XL; Sun, CY; Zhang, YZ; Zhou, BC (2008). Production of novel angiotensin I converting enzyme inhibitory peptides by fermentation of marine shrimp (Acetes chinensis) with Lactobacillus fermentum SM 605. Appl. Microb. Biotech. 79(5): 785-791.

Wu, H; Wang, Q; Ma, T; Ren, J (2009). Comparative studies on the functional properties of various protein concentrate preparations of peanut protein. Food Res. Int'l. 42(3): 343-348. 